\title{
Discovery of a New Analgesic Peptide, Leptucin, from the Iranian Scorpion, Hemiscorpius lepturus
}

\author{
Sedigheh Bagheri-Ziari ${ }^{1}$, Delavar Shahbazzadeh ${ }^{1}$, Soroush Sardari ${ }^{2}$, Jean-Marc Sabatier ${ }^{3}$ (i) and \\ Kamran Pooshang Bagheri ${ }^{1, *(D)}$ \\ 1 Venom and Biotherapeutics Molecules Laboratory, Medical Biotechnology Department, \\ Biotechnology Research Center, Pasteur Institute of Iran, Tehran 1316943551, Iran; \\ sebagheri2000@gmail.com (S.B.-Z.); shahbazzadeh@yahoo.com (D.S.) \\ 2 Drug Design and Bioinformatics Unit, Medical Biotechnology Department, Biotechnology Research Center, \\ Pasteur Institute of Iran, Tehran 1316943551, Iran; ssardari@hotmail.com \\ 3 Institute of NeuroPhysiopathology (INP), Faculté de Pharmacie, Université d'Aix-Marseille, UMR 7051, \\ 27 Bd Jean Moulin, CEDEX, 13385 Marseille, France; sabatier.jm1@gmail.com \\ * Correspondence: k_bagheri@pasteur.ac.ir
}

check for updates

Citation: Bagheri-Ziari, S.; Shahbazzadeh, D.; Sardari, S.; Sabatier, J.-M.; Pooshang Bagheri, K. Discovery of a New Analgesic Peptide, Leptucin, from the Iranian Scorpion, Hemiscorpius lepturus. Molecules 2021, 26, 2580. https://doi.org/10.3390/ molecules26092580

Academic Editor: Rosanna Di Paola

Received: 29 March 2021

Accepted: 26 April 2021

Published: 28 April 2021

Publisher's Note: MDPI stays neutral with regard to jurisdictional claims in published maps and institutional affiliations.

Copyright: (c) 2021 by the authors. Licensee MDPI, Basel, Switzerland. This article is an open access article distributed under the terms and conditions of the Creative Commons Attribution (CC BY) license (https:/ / creativecommons.org/licenses/by/ $4.0 /)$.

\begin{abstract}
Hemiscorpius lepturus scorpion stings do not induce considerable pain based on epidemiological surveys conducted in the southwest part of Iran. Accordingly, this study was aimed to identify the analgesic molecule in H. lepturus venom by analyzing a cDNA library of the scorpion venom gland looking for sequences having homology with known animal venom analgesic peptides. The analgesic molecule is a cysteine rich peptide of 55 amino acids. the synthetic peptide was deprotected and refolded. RP-HPLC, Ellman's, and DLS assays confirmed the refolding accuracy. Circular dichroism (CD) showed helix and beta sheet contents. This peptide, called leptucin, demonstrated $95 \%$ analgesic activity at the dose of $0.48 \mathrm{mg} / \mathrm{kg}$ in hot plate assay. Leptucin at the doses of $0.32,0.48$, and $0.64 \mathrm{mg} / \mathrm{kg}$ showed $100 \%$ activity in thermal tail flick test. No hemolysis or cytotoxicity was observed at 8 and $16 \mu \mathrm{g}$. Histopathology evaluations indicated no hepatotoxicity, nephrotoxicity, and cardiotoxicity. We thus report that leptucin is the analgesic agent of H. lepturus venom. Regarding the high in vivo efficacy of leptucin and the fact it shows no observable toxicity, it could be suggested as a drug lead in a preclinical study of acute pain as well as the study of its mechanism of action.
\end{abstract}

Keywords: Leptucin; analgesic peptide; Hemiscorpius lepturus; scorpion

\section{Introduction}

Pain is the most well-known unpleasant experience which protects a human from injuries [1,2]. Injuries cause acute or chronic pain. Acute pain occurs immediately after an injury and is usually severe in nature, whereas chronic pain continues beyond the normal healing process. It can start as acute pain but lasts for more than 3 months. The main causative agents for acute pain include surgery, traumas, bone fractures, dental work, burns or cuts, and for chronic pain lower back pain, cancer, and arthritis [3].

An analgesic is a drug that relieves pain [4]. They are classified into non-opioid analgesics (paracetamol, ibuprofen, COX-2 inhibitors, NSAIDs, diclofenac, etc.) and opioid analgesics (morphine, oxycodone, etc.) [5,6]. Among analgesic drugs, NSAIDs are routinely used for acute pain, but in the case of contraindication and severe pain, opioids are used [5]. Among opioids, morphine is the gold standard for pain relief, but their use is limited due to a number of side effects, including respiratory depression, constipation, intolerance, dependence, and addiction [7]. Thus, the design or discovery of a new molecule with a lesser complication is necessary. Since peptide molecules are more targeted and have fewer side effects than chemical small molecules, analgesic peptides could be a new revolution in pain-relief [8-10]. 
Venomous animals are important sources for discovery or development of new drug leads [11-21]. Approved peptide drugs from the venom of venomous animals include captopril (isolated from the venom of Bothrops jararaca, a pit viper, to control blood pressure), eptifibatide and tirofiban (isolated from viperid snake venom as an antiplatelet drug), lepirudin and bivalirudin (isolated from leech venom as anticoagulants), ziconotide (isolated from cone snails venom to suppress chronic pain), exenatide (isolated from lizard venom to treatment of type 2 diabetes) [15].

Venomous creatures have high potential for discovery or development of peptide drug leads [22-24]. Among the venomous animals, scorpions are also an important source for discovery of potential peptide or protein molecules with different pharmacological activities [24-27].

Some peptides in scorpion venom make scorpion stings very painful [28-30], but the stings of the Iranian scorpion, Hemiscorpius lepturus (H. lepturus) do not cause considerable pain based on local evidence, epidemiological studies, and clinical reports [31-35]. To our best of knowledge, no study has been conducted on the cause of the painless stings of this scorpion.

H. lepturus belongs to the hemiscorpidae family, distributed in Iran, Iraq, Pakistan, and Yemen [36]. To date, some peptides with pharmacological or toxicological activities have been discovered from the venom of H. lepturus venom i.e., hemicalcin [37], hemotoxin [36], hemilipin [38], PLD1 [31], HL2153 and HL2155 [39].

In the present study, we identified in the cDNA library of the H. lepturus scorpion venom gland a peptide homologue to a known analgesic peptide from sea anemone. The peptide was synthetized, refolded, and analyzed for its structure and analgesic activity as well as its toxicity.

\section{Materials and Methods}

\subsection{Materials, Cells, and Animals}

3-(4,5-Dimethyl-2-thiazolyl)-2,5-diphenyl-2H-tetrazolium bromide (MTT) was purchased from Sigma (Saint Louis, MO, USA) and isopropanol, triflouroacetic acid (TFA), and acetonitrile (ACN) were purchased from Merck (Darmstadt, Germany). Morphine sulfate was obtained from Darou Pakhsh Pharmaceuticals (Tehran, Iran). DMEM and fetal bovine serum (FBS) were purchased from Gibco, Life Technologies (Grand Island, NY, USA). Human Embryo Kidney (HEK293, NCBI code C497) was obtained from Pasteur Institute of Iran (Tehran, Iran).

NMRI mice (Male, $25 \mathrm{~g}$ ) were purchased from the Pasteur Institute of Iran. The animals were allowed to adapt for a week in standard conditions with a dark/light cycle of $12 \mathrm{~h}$. The room temperature was $22 \pm 1{ }^{\circ} \mathrm{C}$ and the relative humidity was adjusted at $50 \pm 5 \%$. The animals received a standard pellet diet and fresh tap water. All experiments were approved by the Ethical Committee of the Pasteur Institute of Iran (code number IR.PII.REC.1394.86).

\subsection{Bioinformatics Analyses}

\subsubsection{Data Mining and ORF Determination}

In this study, we used the data from a cDNA library of the venom gland of H. lepturus scorpion, which had been generated by Illumina RNA sequencing in 2017 [31], in order to find the analgesic molecule. The relevant keywords like analgesic, anti-pain, and pain relieving were searched in the annotated library. Then the corresponding DNA sequence was translated to ORF using ORF finder (https: / / www.ncbi.nlm.nih.gov / orffinder /) (accessed on 16 March 2020). 


\subsubsection{Similarity Analysis and Determination of the Mature Chain}

The similarity of ORF was determined against non-redundant and reference sequences using the 'BLASTP' server (http:/ /blast.ncbi.nlm.nih.gov/Blast.cgi) (accessed on 17 March 2020). The mature chain and signal peptide of its similar sequences were checked in NCBI and UniProt. Then, for accurate determination of signal peptide and mature chain, the identified ORF for $H$. lepturus analgesic peptide was multiple aligned against the similar sequences using 'COBALT' server [40]. To control the accuracy of alignment, the evolutionary signature of aligned peptides was determined too. Then the molecular weight of the mature chain was calculated using the 'Protparam' server (http:/ / web.expasy.org/protparam) (accessed on 18 March 2020).

\subsubsection{Prediction of 3D Structure of the Peptide}

The 3D structure of the peptide was predicted using the Iterative Threading Assembly Refinement (I-TASSER) server at Michigan University [41]. A model with the lowest root mean square deviation (RMSD) was selected. This model was viewed and analyzed by using 'UCSF Chimera' software package [42]. Structural alignment with the analgesic peptide of a sea anemone, was performed and visualized using the UCSF Chimera software. Based on 3D structure analysis, disulfide bonds between cysteine amino acids were predicted.

\subsection{Peptide Synthesis}

The peptide was synthesized by an external facility (Biomatik Co., Cambridge, ON, Canada) using the solid phase method and Fmoc (9-fluorenyl-methoxycarbonyl) chemistry. In order to avoid oxidizing the sulfur moieties of cysteine, all cysteines in peptides were protected with acetamidomethyl (ACM) groups. The peptide was amidated at the Cterminal. The peptide was purified up to $95 \%$ by reverse phase-high performance liquid chromatography (RP-HPLC). The molecular weight of the peptide was also confirmed using the mass spectrometry method.

\subsection{Deprotection of the Synthetic Peptide}

In order to refold the peptide and examine its activity, protected groups must be removed. Deprotection was performed based on the molar ratio method [43]. First, $1 \mathrm{mg}$ of the synthesized peptide was dissolved in degassed distilled water. Then $100 \mu \mathrm{L}$ of the peptide solution was added to $900 \mu \mathrm{L}$ of mercury acetate solution $(0.1 \%$ in degassed distilled water) and incubated at RT for $60 \mathrm{~min}$. Then, $10 \mu \mathrm{L}$ of 2-mercaptoethanol $(10 \mathrm{mM})$ was added to the solution, incubated for $30 \mathrm{~min}$ under nitrogen gas, and centrifuged at $10,625 \times g$ for $5 \mathrm{~min}$. The supernatant was collected and freeze-dried at $-55^{\circ} \mathrm{C}$ for $24 \mathrm{~h}$ in a freeze dryer system (alpha 1-2 LD plus; Martin Christ Gefriertrocknungsanlagen $\mathrm{GmbH}$, Osterode am Harz, Germany).The abovementioned method was performed in four $\mathrm{pH}$ protocols. The peptide was dissolved in two $\mathrm{pH}$ conditions (i.e., 4 and 7) and the deprotection of peptides was subsequently performed in two $\mathrm{pH}$ conditions (i.e., 4 and 7).

\subsubsection{Quality Control of the Deprotected Peptide by SDS-PAGE}

To compare the yield of peptide in the supernatant and pellet in four $\mathrm{pH}$ protocols, SDS-PAGE was performed using 15\% polyacrylamide gel. The best protocol of deprotection method was considered for further evaluation in RP-HPLC.

\subsubsection{Evaluation of the Accuracy of the Deprotection Method by RP-HPLC}

RP-HPLC was carried out on a Knauer system (Knauer Wissenschaftliche Gerate Co., Berlin, Germany), with C18 column (Beckman-Coulter, Brea, CA, USA) $100 \AA$ A, $250 \times 4.6$ mm). One hundred $\mu \mathrm{L}$ of peptide solution was injected into the injector and a linear gradient of acetonitrile was applied from 0 to $90 \%$ (absolute acetonitrile containing $0.1 \%$ TFA) at a flow rate of $1 \mathrm{~mL} / \mathrm{min}$ for $90 \mathrm{~min}$. After that, the retention time of the deprotected peptide was compared to the protected one. Any alteration in the retention time of the deprotected 
peptide indicates that the peptide is deprotected. The deprotected peptide was collected and lyophilized as mentioned above.

\subsubsection{Determination of the Purity and Yield of the Deprotected Peptide}

The purity of the deprotected peptide was determined by using chromgate software package. The yield was determined by calculation of the difference between the amount of peptide before and after deprotection. The concentration of the peptide was measured by UV estimation at $280 \mathrm{~nm}$ in a spectrophotometer. Yield percent was calculated using the following formula [30]:

$$
\text { Yield percent }=\left(\frac{\text { peptide amount after deprotection }}{\text { peptide amount before deprotection }}\right) \times 100
$$

\subsection{Refolding of the Deprotected Peptide}

At first, ammonium acetate solution $(20 \mathrm{mM}, \mathrm{pH}$ 6.5) prepared in $900 \mu \mathrm{L}$ degassed water for injection (WFI). Then, the different amounts of reduced glutathione (GSH) and oxidized glutathione (GSSG) were added to each vial to reach a ratio of GSH/GSSG as 10:1 (3.07 $\mathrm{mg}: 0.612 \mathrm{mg})$ and 2:1 (0.614 mg: $0.612 \mathrm{mg})$. Ultimately, two amounts of deprotected peptide (40 and $80 \mu \mathrm{g}$ in 50 and $100 \mu \mathrm{L}$, respectively) were added to the separate solutions. The final volume was adjusted to $1 \mathrm{~mL}$ by ammonium acetate solution (20 mM, pH 6.5).Then the solutions were stirred at $22{ }^{\circ} \mathrm{C}$ for $4 \mathrm{~h}$ [44]. All steps were performed under nitrogen gas to ovoid oxidizing the cysteine amino acid residues.

To determine the optimal refolding conditions, RP-HPLC was performed for the sample and negative control (peptide-free buffer) as well. The results were compared to negative control, and the peak corresponding to the refolded peptide was collected and lyophilized. SDS-PAGE was then performed to verify the existence of peptide. Then, the resulting peptide was subjected to Ellman assay to further confirmation of peptide refolding. For the activity assays, the sample was dialyzed against normal saline in a dialysis tube (MWCO: $3000 \mathrm{Da}$ ) for $24 \mathrm{~h}$.

\subsubsection{Determination of the Purity and Yield of the Refolded Peptide}

The purity of the refolded peptide was determined by using chromgate software package. The yield was determined by calculation of the difference between the amount of peptide before and after refolding. The concentration of the peptide was measured by UV estimation at $280 \mathrm{~nm}$ in a spectrophotometer. Yield percent was calculated as detailed above [30].

\subsubsection{Confirmation of Refolding by Ellman's Assay}

This assay was performed to confirm that there is no free thiol residue in the surface of refolded peptide. No reaction is expected for the refolded peptide. This assay was performed based on the protocol developed by Shahangian, et al. [45].

Briefly, refolded peptide $(5 \mathrm{mM})$ incubated with a reaction mixture $(8 \mathrm{M}$ urea, $100 \mathrm{mM}$ sodium-phosphate, $\mathrm{pH}$ 8.0, and $1 \mathrm{mM}$ 5,5'-dithiobis-(2-nitrobenzoic acid) (DTNB)) at room temperature. The optical density (OD) was monitored at $412 \mathrm{~nm}$ after $1 \mathrm{~h}$. The Ellman's reagent solution without refolded peptide was used as negative control. The number of free thiols was calculated using a molar extinction coefficient of $13,600 \mathrm{M}^{-1} \mathrm{~cm}^{-1}$.

\subsection{Dynamic Light-Scattering (DLS)}

To assess the homogeneity of the refolded purified peptide $(100 \mu \mathrm{g}$ in $500 \mu \mathrm{L}$ water/TFA $0.05 \%$ ), DLS analysis was performed at RT and a scattering angle of $90^{\circ}$ using a Zetasizer Nano-ZS instrument (ZEN 3600, Malvern Co., Malvern, UK). A typical protein refractive index of 1.45 was used. 


\subsection{Circular Dichroism}

The secondary structure of the refolded peptide was studied by circular dichroism (CD) spectroscopy using a spectropolarimeter (JASCO J-810, JASCO International Co., Ltd., Tokyo, Japan). At first, the refolded peptide $(200 \mu \mathrm{g})$ was resuspended in $300 \mu \mathrm{L}$ water/TFA $0.05 \%$. The sample was placed into a $0.1 \mathrm{~cm}$ path-length quartz Jasco cell at $25^{\circ} \mathrm{C}$. The spectra were recorded in the range of $190-260 \mathrm{~nm}$ with averaging three scans. The CD spectra of peptide free buffer are also recorded as control similarly. The percent of alpha helix, beta sheet, turn, and coil conformations was calculated using the Spectra Manager ${ }^{\mathrm{TM}}$ II software package.

\subsection{The Evaluation of Analgesic Activity for the Refolded Leptucin}

\subsubsection{Hot Plate Test}

This assay was performed to investigate the central analgesic effect [46]. Briefly, the mice were first placed on $55^{\circ} \mathrm{C}$ hot plate and pain responses (hind paw withdrawal, licking and/or shaking) were recorded. Mice with normal pain responses were selected and randomly divided into six groups (four different doses of peptide, negative control, and positive control); six mice in each group.

The peptide at the doses of $0.16,0.32,0.48$, and $0.64 \mathrm{mg} / \mathrm{kg}(4,8,12$ and $16 \mu \mathrm{g} / \mathrm{mouse})$ were administrated intraperitoneally. Normal saline and morphine $(10 \mathrm{mg} / \mathrm{kg})$ were used as negative and positive control, respectively.

Reference to FDA guidance for testing analgesics, all analgesics has characteristics that create a challenge for clinical trial design. Pain is a subjective phenomenon and often fluctuates over time. Pain intensity changes over a relatively short period of time, which can present challenges in designing a trial. Pain intensity can be measured by numerical rating scales, visual analog scales, or categorical scales [47] (http:/ / www.fda.gov / Drugs/ GuidanceComplianceRegulatoryInformation/Guidances/default.htm) (accessed on 18 February 2021).

Thus, we followed FDA guidance as a realistic approach to recording pain responses. Accordingly, the peptide efficacy was determined as the percent of activity instead of recording latency.

After $30 \mathrm{~min}$, the pain responses in each group were recorded. A cut-off time was set at $40 \mathrm{~s}$. The time periods to recording pain responses were determined at thirtyminute intervals up to $300 \mathrm{~min}$ after administration. Analgesic activity was calculated at each time point [48].

\subsubsection{Tail Flick Test}

This test was performed using a tail flick apparatus (Pooya Armaghan Co., Tehran, Iran) to evaluate central analgesic effect $[49,50]$. The mice were placed horizontally in the mice enclosure, their tails ( $5 \mathrm{~cm}$ from the tip) exposed to the heat radiant, and the tail retraction time was recorded. The baseline latencies of the radiant heat were set to $2.5-3.5 \mathrm{~s}$ to avoid tissue damage and the cut-off latency was adjusted to $10 \mathrm{~s}$. The mice were randomly divided into 6 groups; four doses of peptide, negative control, and positive control. Normal saline and morphine $(10 \mathrm{mg} / \mathrm{kg})$ were used as negative and positive control, respectively. The peptide at the doses of $0.16,0.32,0.48$, and $0.64 \mathrm{mg} / \mathrm{kg}(4,8$, 12 and $16 \mu \mathrm{g} /$ mouse) were administrated intraperitoneally. Then, the latency of the tail reaction in each group was measured before the injection of the peptide or negative and positive controls. Thirty minutes after injection, the tail retraction time was recorded.

\subsection{Toxicity Tests for Leptucin}

\subsubsection{MTT Test}

In order to determine the cytotoxic effect of peptide, MTT assay was done on HEK-293 cell line. The cells $\left(2 \times 10^{4}\right)$ were plated in 96-well plates in DMEM medium, supplemented with $10 \%$ FBS and then incubated in the atmosphere containing $5 \% \mathrm{CO}_{2}$ and $95 \%$ air at $37^{\circ} \mathrm{C}$ for overnight. The peptide, at the concentrations ranging from 16 to $0.25 \mu \mathrm{g} / \mathrm{mL}$, was 
prepared in DMEM medium, added to each well, and incubated for $24 \mathrm{~h}$. A $10 \mu \mathrm{L}$ solution of freshly prepared MTT ( $5 \mathrm{mg} / \mathrm{mL}$ in PBS) was added to each well and incubated for an additional $4 \mathrm{~h}$. Isopropanol $(100 \mu \mathrm{L})$ was then added and the plates were shaken gently to facilitate formazan solubilization. The absorbance was measured at $570 \mathrm{~nm}$ by an ELISA reader (ELx808, BioTek, Winooski, VT, USA), and the viability was then evaluated [51].

\subsubsection{In Vitro Hemolysis Assay}

This assay was performed according to Memar et al.'s protocol [52]. Briefly, human blood from a healthy volunteer was collected, centrifuged at $664 \times g$ for $5 \mathrm{~min}$, and washed with PBS three times.

Two doses of peptide ( $8 \mu \mathrm{g}$ and $16 \mu \mathrm{g}$ ) were prepared in $100 \mu \mathrm{L}$ of PBS $(1 \times)$. One hundred $\mu \mathrm{L}$ of washed RBCs suspension (2\%) was added to each well of a 96-well microplate (Nunc, Sigma Co., St. Louis, MO, USA). Phosphate buffer saline and Triton X-100 (0.1\%) was used as negative and positive control, respectively. The microplate was incubated at $37^{\circ} \mathrm{C}$ for $2 \mathrm{~h}$ and centrifuged at $1664 \times g$ for $10 \mathrm{~min}$. The supernatant was transferred to a new plate and OD was measured at $540 \mathrm{~nm}$ in a microplate spectrophotometer $(\mathrm{EPOCH}$, BioTek, Winooski, VT, USA). The experiment was carried out in triplicate. The degree of hemolysis was determined as the following formula:

$$
[(\mathrm{OD} \text { sample }- \text { OD neg control) } /(\mathrm{OD} \text { pos control }- \text { OD neg control) }] \times 100
$$

\subsubsection{In Vivo Hemolysis Assay}

Three doses of peptide, $0.32,0.48$, and $0.64 \mathrm{mg} / \mathrm{kg}(8,12$, and $16 \mu \mathrm{g} / \mathrm{mouse})$, were injected intraperitoneally and the blood samples were collected after 24 and $48 \mathrm{~h}$. The blood samples were centrifuged at $1180 \times g$ for $5 \mathrm{~min}$, and the absorbance of supernatant was measured at $540 \mathrm{~nm}$ by a microplate spectrophotometer (EPOCH, BioTek, Winooski, VT, USA) [18]. Normal saline was used as negative control.

\subsubsection{Histopathological Study}

Two doses of peptide, 0.32 and $0.64 \mathrm{mg} / \mathrm{kg}$ ( 8 and $16 \mu \mathrm{g} / \mathrm{mouse}$ ), were injected intraperitoneally, and the mice were sacrificed after $48 \mathrm{~h}$ of peptide administration. Liver, kidney, and heart were collected and fixed in 10\% buffered formalin solution. After 4 days, the organ sections were routinely processed in an automated tissue processor and embedded in paraffin wax. The tissue sections were prepared and stained with hematoxylin and eosin (H\&E) for pathological studies [53].

\subsubsection{Determination of Lethal Dose 50}

Lethality due to leptucin was examined on BALB/c mice (male, 20-30 g) using routine method. Leptucin at the doses of $0.8,1.6,2.4,3.2$, and $4 \mathrm{mg} / \mathrm{kg}$ were prepared in $100 \mu \mathrm{L}$ sterile PBS $(1 \times)$ and injected intraperitoneally into each group ( 6 mice/group). Sterile PBS $(1 \times)$ was used as negative control.

\subsection{Motor Coordination Test (Rotarod Test)}

The animals are placed on textured drums $\left(1 \frac{1}{4}\right.$ inch diameter) to avoid slipping. When an animal drops onto the individual sensing platforms, the result is recorded. Five mice were tested at a rate of $4 \mathrm{rpm}$.

Naive mice were trained until they could remain on the rotarod for $5 \mathrm{~min}$. Animals that failed to meet this criterion within three trials were discarded.

Mice were intraperitoneally pretreated with either normal saline or leptucin at the doses of $0.32,0.48$, and $0.64 \mathrm{mg} / \mathrm{kg}(8,12$, and $16 \mu \mathrm{g} / \mathrm{mouse})$. Thirty minutes after the injection of peptide, mice were placed on the rotarod for $5 \mathrm{~min}$. If a mouse fell from the rotarod during this time period, it was scored as motor impaired. The data was subjected to ANOVA followed by Student's t-test [54]. 


\subsection{Data Analysis}

Data obtained from the two pain models tests are expressed as mean \pm SD. Normality was assessed using the Kolmogorov-Smirnov test. The significance of the effect was tested by one-way analysis of variance (ANOVA) followed by Tukey's post hoc analysis. In all cases, the results were considered significant where $p<0.05$. Effect dose of 50\% (ED50) was measured by linear regression assay. LD50 was determined within $72 \mathrm{~h}$ following i.p. administration of leptucin; six mice in each group.

\section{Results}

\subsection{Identification of Mature Chain and Sequence Analysis}

According to the data mining analyses, an $859 \mathrm{bp}$ sequence corresponding to the annotation of analgesic peptide was concluded in the cDNA library. Analysis of the raw sequence in ORF finder server showed a $231 \mathrm{bp}$ sequence encrypted as a peptide of 76 amino acids (Figure 1). Analysis of sequence similarity by blastP showed that the $H$. lepturus analgesic peptide was similar to different peptides with identity ranging from 47.37 to $42.47 \%$ (Figure 2). TauPI-stichotoxin-Hcr2b (UniProt P0DMJ5, AltName: APHC1), an analgesic peptide from the sea anemone; Heteractis crispa, had the highest similarity (Identity $47 \%$ ) to H. lepturus analgesic peptide (Figure 2). The obtained result reconfirmed the accuracy of annotation analysis of cDNA library of H. lepturus venom gland.

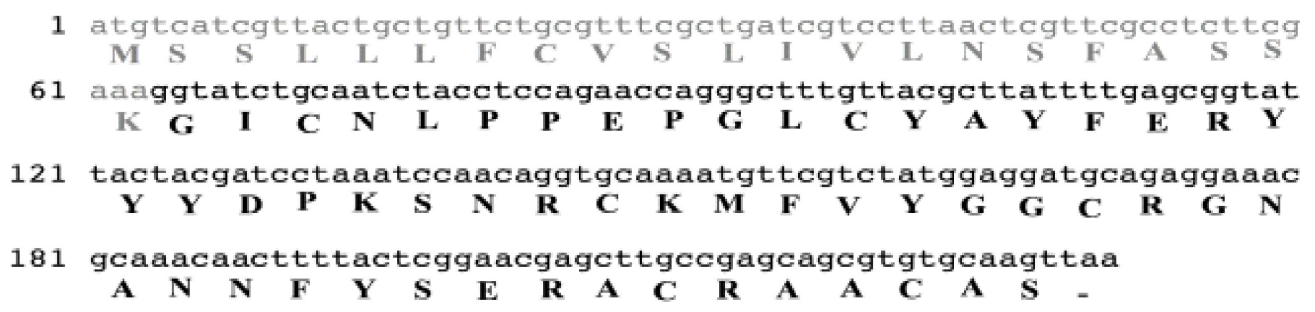

Figure 1. The amino acid and ORF sequence of leptucin; the H. lepturus analgesic peptide. The area of the signal peptide and mature chain are colored gray and black respectively.

NCBI Multiple Sequence Alignment Viewer, Version 1.19.1

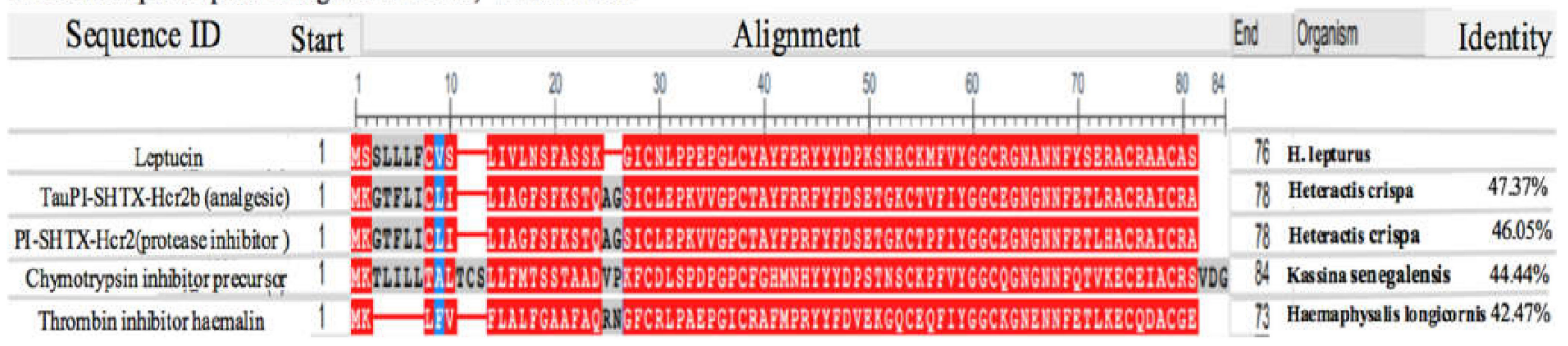

Figure 2. Multiple alignment of leptucin with selected similar peptides by COBALT server. Leptucin's ORF was compared to its closest similar peptides. As shown in the figure, that was similar to different peptides with identity ranging from 47.37 to $42.47 \%$. Also, analysis showed a conserved signature sequence in the selected similar sequences as [C (6XGX) C (8XYXD5X) C (2XFXYGG) C (XGNXNNF5X) C (3X) C (2X)].

Multiple alignment analyses showed a conserved signature in the selected similar peptides as [C (6XGX) C (8XYXD5X) C (2XFXYGG) C (XGNXNNF5X) C (3X) C (2X)]. In all selected similar peptides, the signal peptide consisted of 22 amino acids, except for one, which were 15 amino acids.

The sequence comparison between $H$. lepturus analgesic peptide and similar peptides led to determination of the mature chain in H. Lepturus analgesic peptide. The mature chain is a cysteine-rich peptide which contains 55 amino acids (Figure 1), hereafter designated as leptucin and its theoretical molecular weight was calculated as 6262.09 Da. 


\subsection{Prediction of 3D Structure of the Peptide}

The predicted structure of leptucin contains two $\beta$ sheets and one $\alpha$ helix (Figure 3A). Disulfide bonds between cysteine amino acids were determined by UCSF Chimera software packages (Figure 3B). Structural alignment of leptucin with TauPI-stichotoxin-Hcr2b [55] by UCSF Chimera software package showed a significant homology $(\mathrm{RMSD}=1.085)$ as depicted in Figure 3C.

(A)

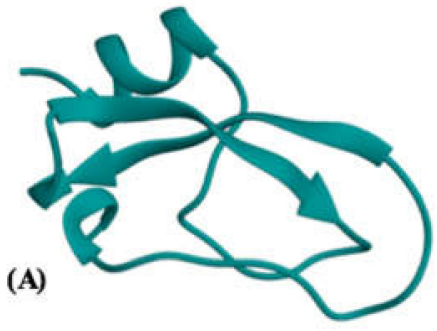

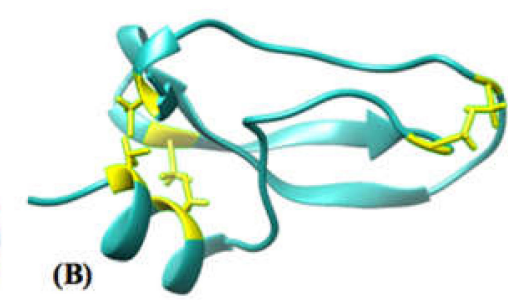

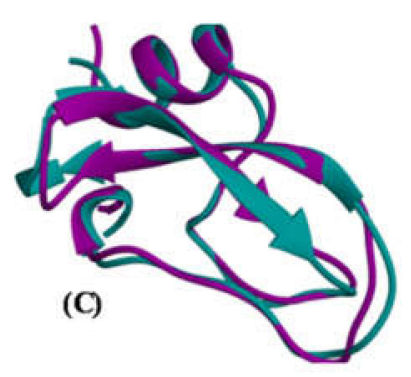

Figure 3. (A) Prediction of the 3D structure of leptucin. Analysis of the result showed that the peptide comprises alpha helices $(25.45 \%)$, beta sheets $(25.45 \%)$, and random coil $(49.09 \%)$. (B) Based on 3D structure, disulfide bonds between cysteine amino acids were predicted in leptucin as $\mathrm{C}_{1}-\mathrm{C}_{6}{ }^{*} \mathrm{C}_{2}-\mathrm{C}_{4}{ }^{*} \mathrm{C}_{3}-\mathrm{C}_{5}$. (C) Superimposition of the structure of TauPIstichotoxin-Hcr2b with the predicted structure of leptucin.

\subsection{Deprotection Analysis}

Based on the molar ratio deprotection method, the peptide dissolved in $\mathrm{pH} 4$ and after that added to deprotection solution ( $\mathrm{pH} 4$, protocol 1). SDS-PAGE was performed on the supernatant and pellet to control the efficiency of the protocols. The results showed that the peptide was degraded and no band was seen. It was speculated that deprotected peptide would be degraded in this $\mathrm{pH}$. In order to overcome this issue, different protocols were used as detailed in Table 1.

Table 1. Different $\mathrm{pH}$ in the molar ratio deprotection method.

\begin{tabular}{cccc}
\hline \multirow{2}{*}{ Deprotection } & Dissolution & \multicolumn{2}{c}{$\mathrm{pH}$} \\
\cline { 3 - 4 } & & 4 & 7 \\
\hline \multirow{2}{*}{$\mathrm{pH}$} & 4 & Protocol 1 & Protocol 3 \\
\cline { 3 - 4 } & 7 & Protocol 2 & Protocol 4 \\
\hline
\end{tabular}

SDS-PAGE was finally performed on the supernatants and pellets of all 3 protocols. The SDS-PAGE results showed that the band density in the supernatant of protocol 2 and 4 is approximately the same and was greater than protocol 3 (Figure $4 \mathrm{~A}, \mathrm{~B}$ ). There was a thin deprotected peptide band in the pellet of protocol 4, but no band was seen in the pellet of protocol 2. According to the results, protocol 2 was considered the optimal protocol. 


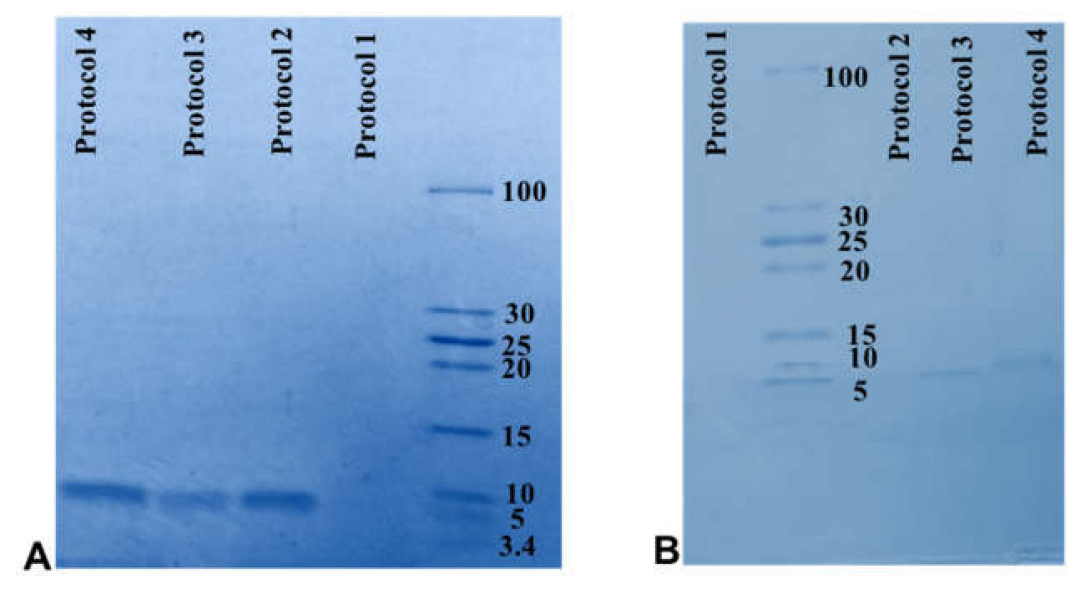

Figure 4. SDS-PAGE performed on the pellets and supernatants. (A) SDS-PAGE on the supernatant showed that the peptide destroyed in protocol 1 . The result showed that the peptide amount obtained in protocol 2 (peptide in $\mathrm{pH} 4$, deprotection in $\mathrm{pH} 7$ ) and 4 (peptide in $\mathrm{pH} 7$, deprotection in $\mathrm{pH} 4$ ) were more than protocol 3 (peptide in $\mathrm{pH} 7$, deprotection in $\mathrm{pH} 7$ ). (B) SDS-PAGE on the pellets showed that peptide band did not exist in protocol 1 (peptide in $\mathrm{pH} 4$, deprotection in $\mathrm{pH} 4$ ), but in protocol 3 (peptide in $\mathrm{pH} 7$, deprotection in $\mathrm{pH} 7$ ) and protocol 4 (peptide in $\mathrm{pH} 7$, deprotection in $\mathrm{pH}$ 4) there were a little deprotected peptide.

\subsection{The Accuracy of Deprotection}

To confirm the accuracy of deprotection, RP-HPLC was performed. One hundred $\mu \mathrm{L}$ of the peptide (in supernatant), collected from the best deprotection protocol, was injected onto a C18 column. RP-HPLC analysis showed that the retention time of the deprotected peptide (Figure 5A) had shifted 1.8 min to the right (Figure 5B) in comparison to the protected peptide.
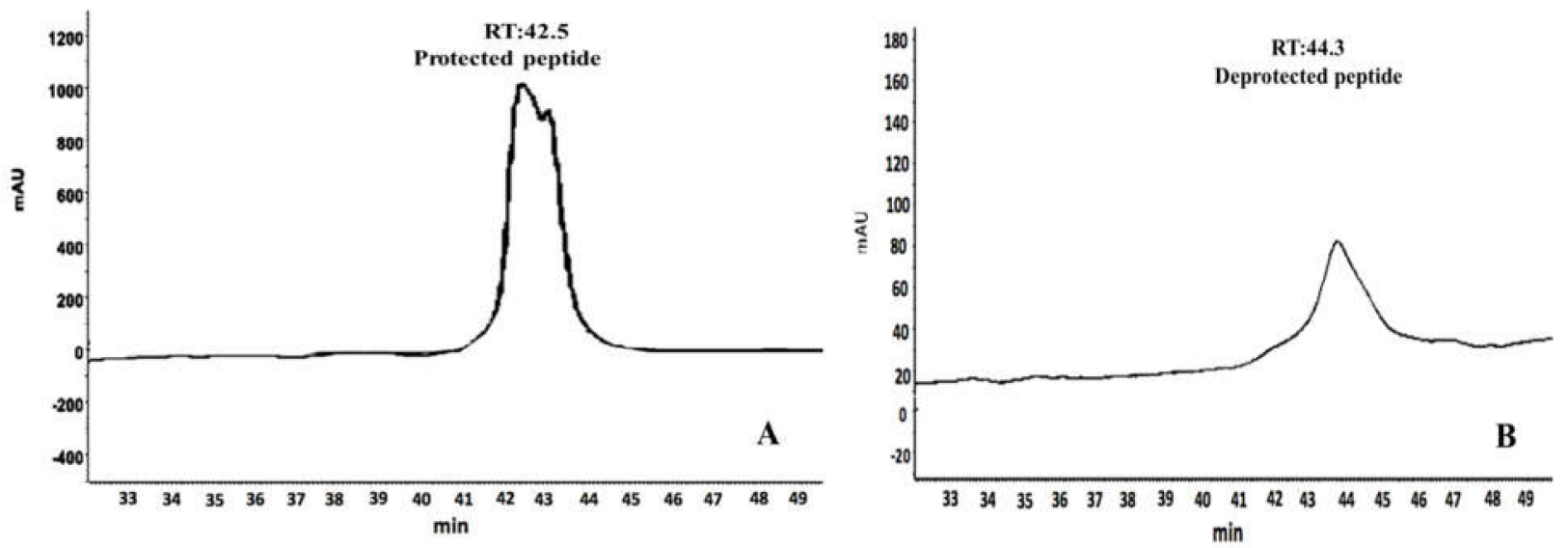

Figure 5. Comparison of the retention time between deprotected and protected in RP-HPLC. ACM protected (A) and deprotected (B). The retention time after deprotection shifted $1.8 \mathrm{~min}$ to the right.

One major peak was seen in the chromatogram and its purity calculated as $92 \%$ by chromgate software (Figure 5B). A total of $114 \mu \mathrm{g}$ deprotected peptide recovered from $300 \mu \mathrm{g}$ protected one, indicating the yield as $38 \%$. 


\subsection{Refolding Analysis}

After refolding of the deprotected peptide in the different ratio of GSH/GSSG, RPHPLC was performed. The results show that there isn't any peak of refolded peptide at the amount of $40 \mu \mathrm{g}$ in the ratios of GSH2/GSSG1 and GSH10/GSSG1 in comparison to negative control. After changing the amount of peptide to $80 \mu \mathrm{g}$, in a ratio of GSH2/GSSG1 a sharp peak was observed. The amount of $80 \mu \mathrm{g}$ peptide in a ratio of GSH10/GSSG1 concluded two peaks (Figure S1). The refolding of $80 \mu \mathrm{g}$ peptide in the ratio of GSH2/GSSG1 concluded the best result in which just one peak was observed (Figure 6).

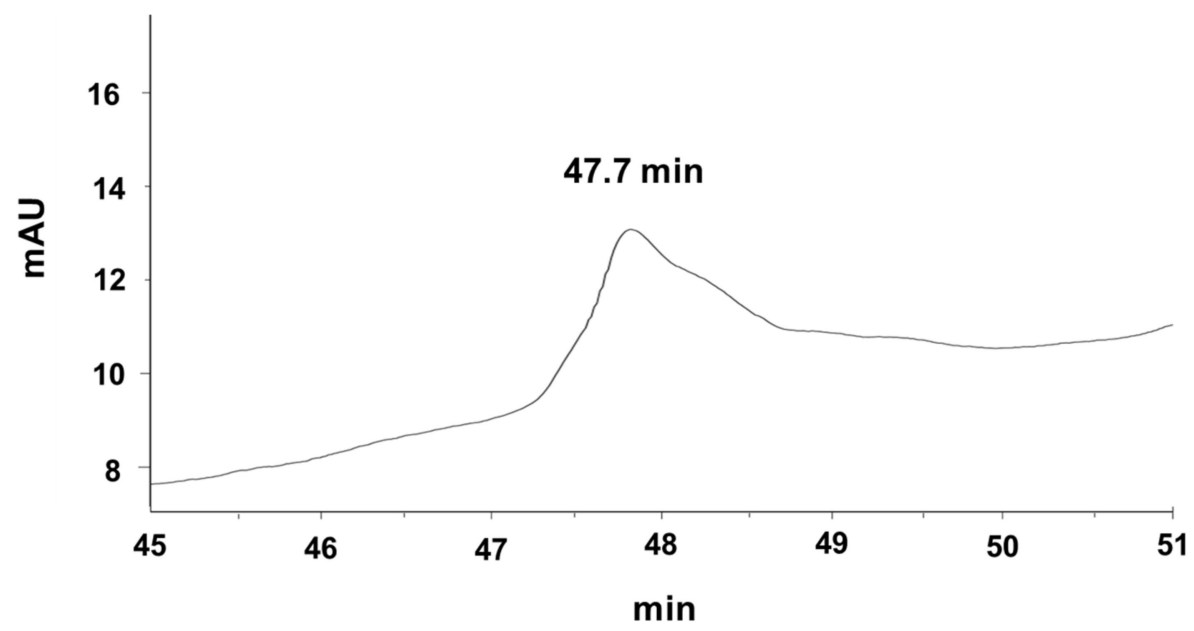

Figure 6. RP-HPLC for the refolding peptide. The refolding of $80 \mu$ g peptide in the ratio GSH2/GSSG1 concluded the best result in which just one peak was observed.

Analysis of the RP-HPLC results showed that the retention time of the refolded peptide had shifted $3.4 \mathrm{~min}$ to the right in comparison to the deprotected peptide.

The purity of the refolded peptide was calculated as $90 \%$ by chromgate software. A total of $108.3 \mu \mathrm{g}$ refolded peptide recovered from $114 \mu \mathrm{g}$ deprotected one. Based on the calculation, the yield of refolding was reported as $95 \%$.

\subsection{Refolding Confirmation}

The refolded peptide was shown by SDS-PAGE (Figure 7A). According to the result, obtained from Ellman's assay, no free thiol residue was detected in the refolded peptide indicating all cysteine residues participated in the formation of disulfide bridges in the peptide. The homogeneity of refolded peptide was analyzed using DLS. The result showed that the homogeneity in the refolded peptide was 95.6\% (Figure 7B).
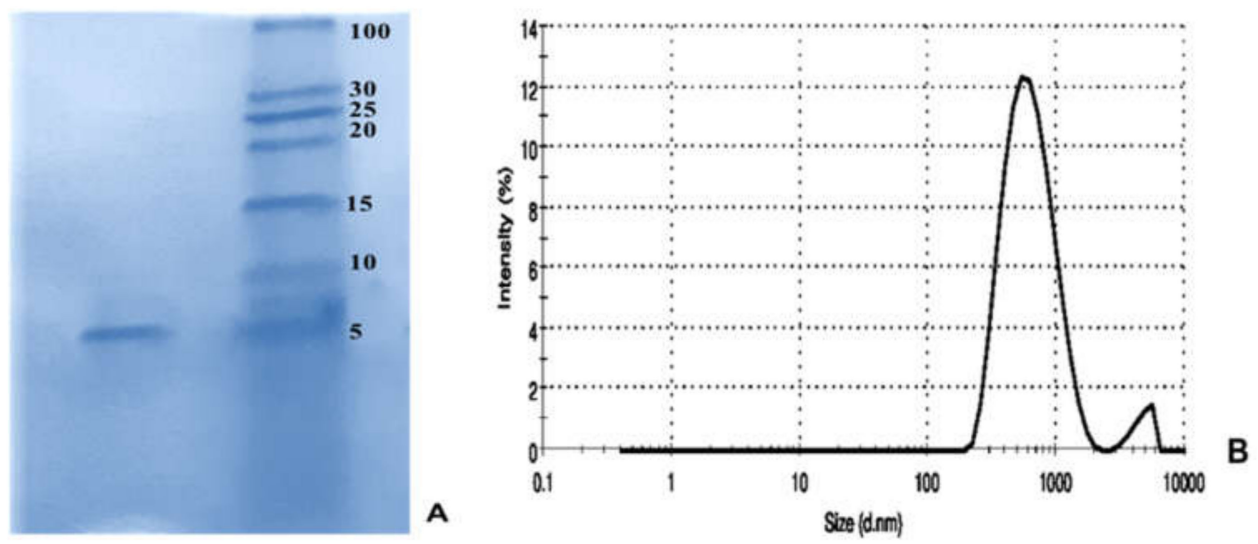

Figure 7. Refolding confirmation. (A) SDS-PAGE for the refolded leptucin, (B) Homogeneity evaluation of the refolded peptide using dynamic light scattering. 


\subsection{Circular Dichroism}

The CD spectrum of leptucin showed a negative band in the 208-222 $\mathrm{nm}$ region, which is characteristic of an $\alpha$-helical structure. Also, one broad negative band around $217 \mathrm{~nm}$ and a shoulder around $195 \mathrm{~nm}$ were observed corresponding to a $\beta$-sheet structure (Figure 8). The proportions of $\alpha$ helices, $\beta$ strands, turns, and random coils were calculated to be equal to $20.4,43.1,11.6$, and $25 \%$, respectively.

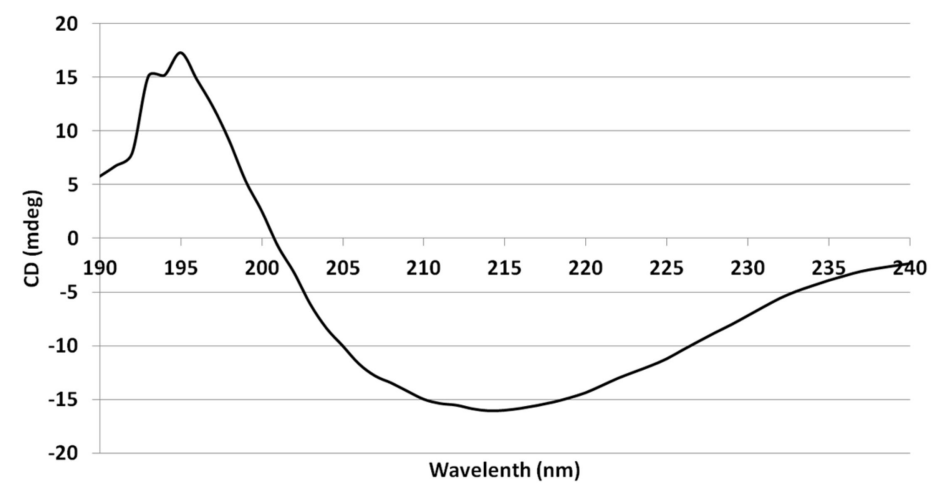

Figure 8. The CD spectra of leptucin. Analysis of the results showed that the peptide comprises alpha helices $(20.4 \%)$, beta sheets $(43.1 \%)$, turn (11.6\%), and random coil (25\%).

\subsection{Activity Assays}

\subsubsection{Hot Plate Assay}

The mice were treated with peptide at the amount of $0.16,0.32,0.48$, and $0.64 \mathrm{mg} / \mathrm{kg}$ $(4,8,12$, and $16 \mu \mathrm{g} / \mathrm{mouse})$ or morphine at $10 \mathrm{mg} / \mathrm{kg}(200 \mu \mathrm{g} / \mathrm{mouse})$. The results showed a significant increase in the analgesic effect in comparison to negative control $(p<0.0001)$, with the exception of $0.16 \mathrm{mg} / \mathrm{kg}$. The maximum analgesic effect (activity $95 \%)$ for the peptide was obtained at the dose of $0.48 \mathrm{mg} / \mathrm{kg}(12 \mu \mathrm{g} /$ mouse) after $30 \mathrm{~min}$ and continued up to the time point of $180 \mathrm{~min}$. No differences were detected between peptide-treated groups of 0.32 and $0.64 \mathrm{mg} / \mathrm{kg}(p>0.05)$ (Figure 9). The $\mathrm{ED}_{50}$ value was equal to $0.19 \mathrm{mg} / \mathrm{kg}(4.9 \mu \mathrm{g} /$ mouse $)$.
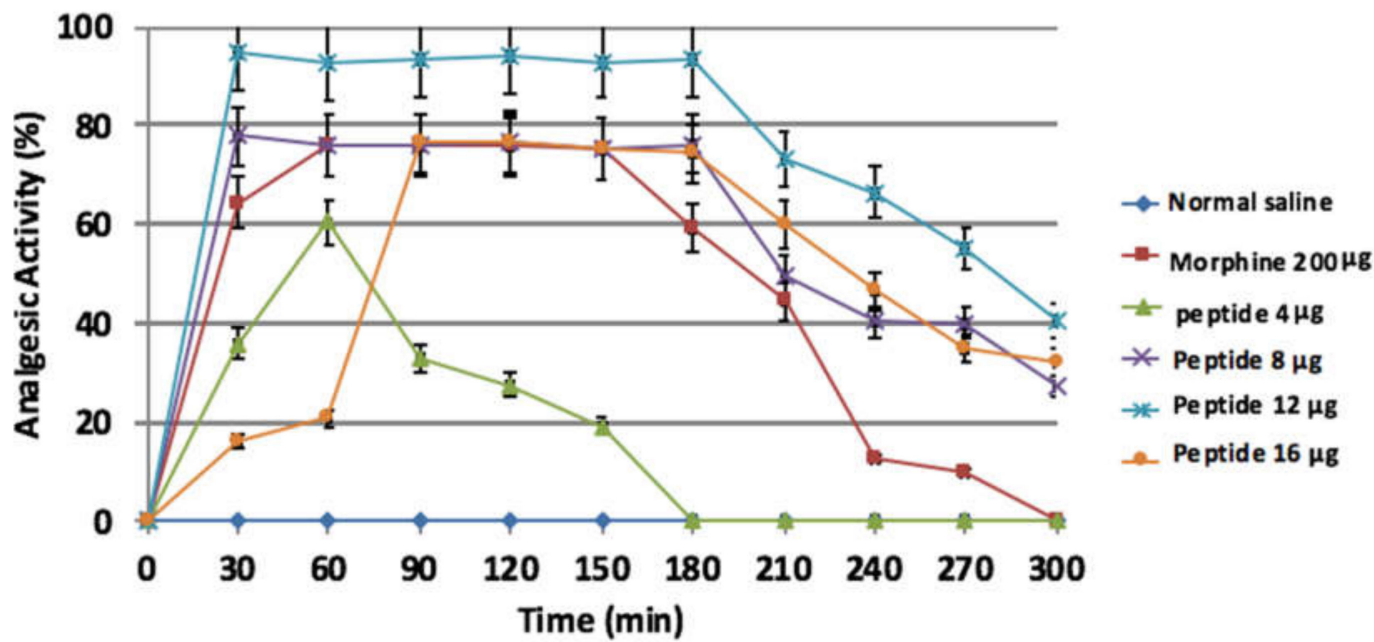

Figure 9. Hot plate assays. The maximum analgesic activity was $95 \%$ at $0.48 \mathrm{mg} / \mathrm{kg}(12 \mu \mathrm{g} / \mathrm{mouse})$ after $30 \mathrm{~min}$ and continued up to the time point of $180 \mathrm{~min}$. Data is expressed as mean \pm SD. All groups had $\mathrm{n}=6$. 


\subsubsection{Tail Flick Assay}

Based on statistical analyses by using ANOVA, the peptide significantly increased the pain threshold at the doses of $0.16,0.32,0.48$, and $0.64 \mathrm{mg} / \mathrm{kg}(4,8,12$, and $16 \mu \mathrm{g} / \mathrm{mouse})$, and there were significant differences between the test and control groups $(p<0.0001)$. The maximum analgesic effect of peptide was obtained at the doses of $0.32,0.48$, and $0.64 \mathrm{mg} / \mathrm{kg}$ after $60 \mathrm{~min}(p>0.05)$. The latency of pain threshold continued at the doses of $0.32,0.48$, and $0.64 \mathrm{mg} / \mathrm{kg}$ for $120 \mathrm{~min}$ but did not last for morphine (Figure 10). The $\mathrm{ED}_{50}$ value of leptucin was equal to $0.17 \mathrm{mg} / \mathrm{kg}(4.3 \mu \mathrm{g} / \mathrm{mouse})$.

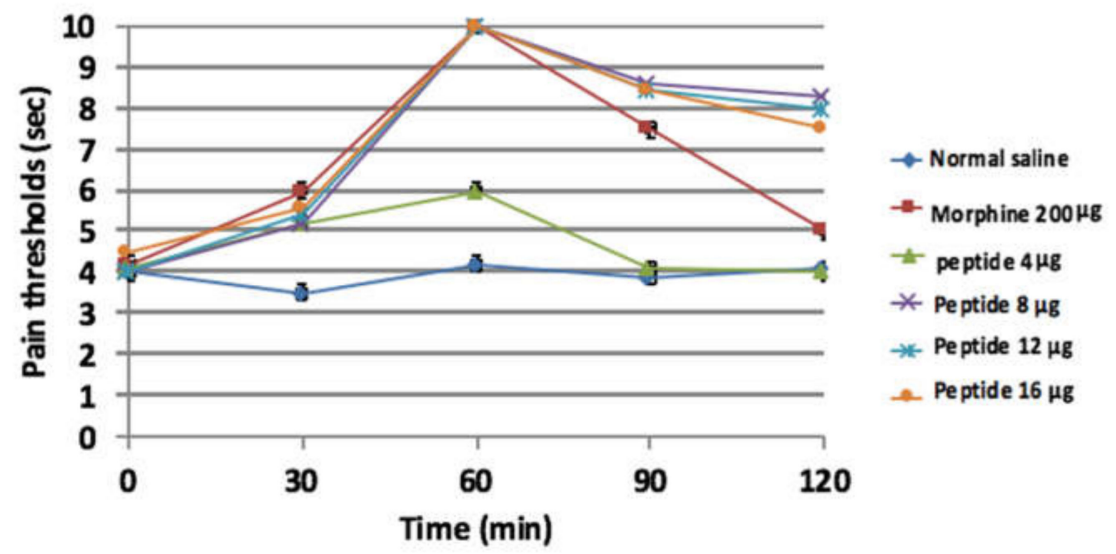

Figure 10. Tail-flick assay. The mice were treated by leptucin or morphine. The maximum analgesic activity of leptucin was obtained after $60 \mathrm{~min}$ at the doses of $0.32,0.48$, and $0.64 \mathrm{mg} / \mathrm{kg}(8,12$, and $16 \mu \mathrm{g} /$ mouse). This result was similar to morphine $(p>0.05)$. Data are expressed as mean $\pm \mathrm{SD}$. All groups had $\mathrm{n}=6$.

\subsection{Toxicity Assays}

The analgesic peptide showed no toxicity on HEK293 cells at all examined concentrations (Figure S2). No toxicity was seen on human RBCs at the doses of 8 and $16 \mu \mathrm{g}$ (Table S1). The results obtained from the in vivo hemolysis assay indicated no toxicity after 24 and $48 \mathrm{~h}$ at all examined doses (Table S2). Histopathology evaluation of liver, kidney, and heart showed that administration of analgesic peptide induces no hepatotoxicity (Figure S3), nephrotoxicity (Figure S4) and cardiotoxicity (Figure S5) up to $0.64 \mathrm{mg} / \mathrm{kg}$ (16 $\mu \mathrm{g} /$ mouse). $\mathrm{LD}_{50}$ value of leptucin was $>4 \mathrm{mg} / \mathrm{kg}$ (100 $\mu \mathrm{g} /$ mouse) (Table S3).

\subsection{Influence of Leptucin on Motor Coordination}

In comparison to control group, leptucin had no effect on motor coordination $(p>0.05)$ which means that the peptide did not cause motor deficits in mice.

\section{Discussion}

NSAIDs and morphine are the most common analgesic in acute pain [5], but their use is limited due to many side effects [7]. Concerning this issue, the design or discovery of a new molecule with lesser complication is necessary $[8,9]$.

Using a screening strategy and bioinformatics analysis, we identified a sequence of an analgesic peptide in the annotated cDNA library of $H$. lepturus. Using multiple alignment analyses, the mature chain of peptide was determined and designated as Leptucin, which is a cysteine-rich peptide. Moreover, for the first time, an evolutionary signature was also determined [i.e., C (6XGX) C (8XYXD5X) C (2XFXYGG) C (XGNXNNF5X) C (3X) C (2X)] in the peptide sequence referring to its considerable similarity with other peptides in the Kunits-type cysteine-rich peptide family.

$3 \mathrm{D}$ prediction showed that the peptide comprises $\alpha$ helices ( $25.45 \%), \beta$ sheets $(25.45 \%)$, and random coil ( $49.09 \%)$ where the amounts of $\alpha$ helices, $\beta$ strands, turns, and random coil 
were calculated to be equal to $20.4,43.1,11.6$, and $25 \%$ respectively. The results obtained from $3 \mathrm{D}$ prediction and $\mathrm{CD}$ analysis thus did not match.

Preliminary analysis based on structural prediction and observation of structural similarity indicated that refolding is necessary for analgesic activity of leptucin.

In all deprotection methods, from the earliest established by Veber on cysteine-rich peptides [56], and then the modified Veber et al.'s protocol (Becker et al.'s protocol) [57], to the method of Eisapoor et al., which was the best method of deprotection [43], it's a common point. In these methods, the removal of the ACM group with mercury acetate had been performed in $\mathrm{pH} 4[43,56,57]$.

In this study, we used the molar ratio protocol for deprotection of leptucin because of its high yield, rapid and cost-effective advantages [43]. Our result showed that the peptide is destroyed in $\mathrm{pH} 4$ after one day. Thus, to overcome this problem, we examined four $\mathrm{pH}$ protocols as mentioned in Table 1. Although deprotection could be performed immediately without peptide degradation, but in terms of stability it is better to reach an optimized protocol to avoid degradation during solubilization and storage.

According to the result, the peptide was seen in the collected supernatant in protocol 2. This finding is not in agreement with Becker et al., Veber et al., and Eisapoor et al.'s protocols as they had found the peptide in the precipitate. This finding can be so interesting in terms of industrial parameters. Being soluble in supernatant is cost-effective since the steps and the time for deprotection are decreased.

Among refolding methods, the methods based on the implementation of reduced and oxidized glutathione and guanidine chloride induce correct refolding in comparison to the other methods [44,58]. According to a 2006 study by Edward et al., guanidine is denaturing and can disrupt the three-dimensional structure of peptides. Thus, we preferred to use reduced and oxidized glutathione for refolding [59]. Refolding plays an important role in the stability and activity of the cysteine-rich peptides [60].

The refolding of cysteine-rich peptides depends on the peptide concentration and the ratio of GSH and GSSG. Different ratios of GSH and GSSG are used to refold different peptides [60,61]. In this study, a ratio of GSH10:GSSG1 and a minimum ratio of 2:1 with 40 and $80 \mu \mathrm{g}$ of peptide were considered. The results showed that the ratio of 2:1 with $80 \mu \mathrm{g}$ of peptide is the optimal molar ratio. The refolding was quite economical in terms of consuming reagents. The refolded peptide in this ratio showed one peak and shifted to the right in comparison to the deprotected peptide as shown in RP-HPLC. Using a ratio of GSH2: GSSG1, our study is in agreement with Lopez-Vera et al., and Buczek, et al. [42,58]. Based on Ellman's result, it can be concluded that there is no free thiol moiety in the surface structure of leptucin and the refolding is done correctly. Based on the results obtained from DLS, the refolded peptide is mono-dispersed and homogenous [62].

Analgesic effects of leptucin were assessed using two well-known models of pain including hot plate and tail flick assays. Leptucin, at the doses of 0.32 and $0.48 \mathrm{mg} / \mathrm{kg}$ ( 8 and $12 \mu \mathrm{g} /$ mouse) demonstrated maximum analgesic effect in tail-flick and hot plate assays, respectively. Analysis of the data obtained from tail flick and hot plate assays showed that leptucin has about 31.25- and 20.83-fold greater activity than morphine. Thus, it can be deduced that leptucin has more specificity towards the responsible channels for pain. This issue demonstrates that the peptide can exert less or no toxicity in comparison to morphine. The primary pathological evaluations and survival assay showed no toxicity in terms of acute toxicity. This fact may raise the hope for using this peptide for relieving acute pain as well as chronic pains, however, comprehensive toxicity studies should be performed.

According to the hot plate assay, the maximum effect of leptucin (activity 95\%) was observed $30 \mathrm{~min}$ after administration and its maximum activity was constant for $150 \mathrm{~min}$ whereas in morphine group, the maximum effect $(76.2 \%)$ was constant for 90 .

As shown in the tail-flick assay, the maximum activity $(100 \%)$ for leptucin was obtained after $60 \mathrm{~min}$. The activity decreased slowly to $86 \%$ and was constant up to $120 \mathrm{~min}$. In the morphine group, the maximum activity of $100 \%$ was seen after $60 \mathrm{~min}$, but the activity decreased slowly to $0 \%$ up to $120 \mathrm{~min}$. 
Morphine is generally accepted to act at supraspinal sites or directly on spinal opioid receptors [63]. Thus, analgesic activity of leptucin in both of hot plate and tail-flick tests suggests that leptucin may act at supraspinal sites and directly on spinal opioid receptors too. Tail flick and hot plate assays are the most common tests of nociception. The nociceptive experience is short-lasting in acute pain models [2]. Therefore, it is suggested that Leptucin has an analgesic effect in an acute pain model.

Based on the analgesic activity and the sequence similarity, it would be interesting to test leptucin activity on ion channels of nociception TRPV1 [55].

Our result showed that leptucin at the dose of 8 and $16 \mu \mathrm{g}$ had no toxicity on human red blood cells. In vivo hemolysis assay on mice demonstrated no hemolysis too.

Also, the peptide had no toxicity on HEK293 cell line by MTT assay up to $16 \mu \mathrm{g}$. Moreover, histopathological sections of liver, kidney, and heart demonstrated that Leptucin had no toxicity up to $0.64 \mathrm{mg} / \mathrm{kg}$.

\section{Conclusions}

We discovered that leptucin is the analgesic agent of H. lepturus venom. Optimization of $\mathrm{pH}$ in deprotection steps led to obtaining the deprotected peptide in the supernatant. This point is important in terms of cost-effectiveness in the laboratory and industrial scale. According to the results gathered in Ellman's test, DLS, and spectropolarimetry, the peptide was refolded successfully.

Regarding the high in vivo efficacy of leptucin and showing no observed toxicity, it could be suggested as a drug lead. Further studies should be performed to decipher more details about its action mechanism. Since peptide molecules can target specific channel and have fewer side effects than chemical small molecules, leptucin would be a new hope in pain-relief.

Supplementary Materials: The following are available online, Figure S1: RP-HPLC for the refolding peptide, Figure S2: MTT assay for leptucin, Figure S3: The histopathology evaluation of liver, Figure S4: The histopathology evaluation of kidney, Figure S5: The histopathology evaluation of heart. Table S1: In vitro hemolysis assay for leptucin, Table S2: In vivo hemolysis for leptucin, Table S3: Determination of LD50 for leptucin.

Author Contributions: S.B.-Z. contributed to practical assays, bioinformatics analyses, and to writing the manuscript. D.S. and J.-M.S. served as advisor and contributed to the revision of the manuscript. S.S. contributed to $\mathrm{CD}$ assay and analyses, and revision of the manuscript. K.P.B. supervised the project and contributed to experimental design, all bioinformatics assays and analyses, writing, revision, and redaction of the manuscript. The idea for discovery of an analgesic peptide from H. lepturus venom belongs to K.P.B. and D.S. All authors have read and agreed to the published version of the manuscript.

Funding: This paper is the part of the PhD thesis of Sedigheh Bagheri-Ziari; approved and funded by Pasteur Institute of Iran. The APC was funded by Jean-Marc Sabatier.

Institutional Review Board Statement: The study was conducted according to the guidelines of the Declaration of Helsinki, and approved by the Institutional Ethics Committee of Pasteur Institute of Iran (protocol code IR.PII.REC.1394.86, 22 June 2018). All experiments were approved by the Ethical Committee of the Pasteur Institute of Iran (code number IR.PII.REC.1394.86).

Informed Consent Statement: Not applicable.

Data Availability Statement: The data presented in this study are available in the manuscript.

Conflicts of Interest: The authors declare no conflict of interest.

Sample Availability: Samples of the compounds are not available from the authors. 


\section{References}

1. Shilpi, J.A.; Uddin, S.J. Analgesic and antipyretic natural products. Medicinal Natural Products. Dis. Focus. Approach 2020, 55, 435.

2. Feng, J.; Lepetre-Mouelhi, S.; Gautier, A.; Mura, S.; Cailleau, C.; Coudore, F.; Hamon, M.; Couvreur, P. A new painkiller nanomedicine to bypass the blood-brain barrier and the use of morphine. Sci. Adv. 2019, 5, eaau5148. [CrossRef]

3. Abd-Elsayed, A.; Deer, T.R. Different Types of Pain. In Pain; Abd-Elsayed, A., Ed.; Springer: Berlin/Heidelberg, Germany, 2019. [CrossRef]

4. Hena, S.; Znad, H. Membrane bioreactor for pharmaceuticals and personal care products removal from wastewater. In Comprehensive Analyti-Cal Chemistry; Elsevier: Amsterdam, The Netherlands, 2018; Volume 81, pp. 201-256.

5. Munir, M.A.; Enany, N.; Zhang, J.-M. Nonopioid Analgesics. Anesthesiol. Clin. 2007, 25, 761-774. [CrossRef]

6. Kumar, M.; Shete, A.; Akbar, Z. A review on analgesic: From natural sources. Int. J. Pharm. Biol. Arch. 2010, 1, 95-100.

7. Cui, J.M.; Zhao, L.; Wang, Z.J.; Ma, M.T.; Wang, Y.; Luo, K.Y.; Wang, L.Q.; Wei, S.; Zhang, X.H.; Han, C.Z.; et al. MEL endomorphins act as po-tent inflammatory analgesics with the inhibition of activated non-neuronal cells and modulation of pro-inflammatory cytokines. Neuropharmacology 2020, 168, 107992. [CrossRef]

8. Bruno, B.J.; Miller, G.D.; Lim, C.S. Basics and recent advances in peptide and protein drug delivery. Ther. Deliv. 2013, 4, 1443-1467. [CrossRef] [PubMed]

9. Lau, J.L.; Dunn, M.K. Therapeutic peptides: Historical perspectives, current development trends, and future directions. Bioorg. Med. Chem. 2018, 26, 2700-2707. [CrossRef]

10. Maatuf, Y.; Geron, M.; Priel, A. The Role of Toxins in the Pursuit for Novel Analgesics. Toxins 2019, 11, 131. [CrossRef] [PubMed]

11. Newman, D.J.; Cragg, G.M. Natural Products as Sources of New Drugs from 1981 to 2014. J. Nat. Prod. 2016, 79, 629-661. [CrossRef] [PubMed]

12. Sable, R.; Parajuli, P.; Jois, S. Peptides, Peptidomimetics, and Polypeptides from Marine Sources: A Wealth of Natural Sources for Pharmaceutical Applications. Mar. Drugs 2017, 15, 124. [CrossRef]

13. Escoubas, P.; King, G.F. Venomics as a drug discovery platform. Expert Rev. Proteom. 2009, 6, 221-224. [CrossRef]

14. Moghadasi, Z.; Shahbazzadeh, D.; Jamili, S.; Mosaffa, N.; Bagheri, K.P. Significant Anticancer Activity of a Venom Fraction Derived from the Persian Gulf Sea Anemone, Stichodactyla haddoni. Iran. J. Pharm Res. 2020, 19, 402-420. [PubMed]

15. Pennington, M.W.; Czerwinski, A.; Norton, R.S. Peptide therapeutics from venom: Current status and potential. Bioorg. Med. Chem. 2018, 26, 2738-2758. [CrossRef]

16. Zarghami, V.; Ghorbani, M.; Bagheri, K.P.; Shokrgozar, M.A. Melittin antimicrobial peptide thin layer on bone implant chitosanantibiotic coatings and their bactericidal properties. Mater. Chem. Phys. 2021, 263, 124432. [CrossRef]

17. Harvey, A.L. Toxins and drug discovery. Toxicon 2014, 92, 193-200. [CrossRef] [PubMed]

18. Pashaei, F.; Bevalian, P.; Akbari, R.; Bagheri, K.P. Single dose eradication of extensively drug resistant Acinetobacter spp. In a mouse model of burn infection by melittin antimicrobial peptide. Microb. Pathog. 2019, 127, 60-69. [CrossRef] [PubMed]

19. Khozani, R.S.; Shahbazzadeh, D.; Harzandi, N.; Feizabadi, M.M.; Bagheri, K.P. Kinetics study of antimicrobial peptide, melittin, in simultaneous bio-film degradation and eradication of potent biofilm producing MDR Pseudomonas aeruginosa isolates. Int. J. Pept. Res. Ther. 2019, 25, 329-338. [CrossRef]

20. Dezfuli, H.T.; Shahbazzadeh, D.; Eidi, A.; Bagheri, K.P.; Pakravan, N.; Amini, S.; Aghasadeghi, M.R.; Mahdavi, M. Induction of IFN- $\gamma$ cytokine re-sponse against hepatitis B surface antigen using melittin. Gastroenterol. Hepatol. Bed. Bench. $2014,7,108-117$.

21. Akbari, R.; Hakemi-Vala, M.; Pashaie, F.; Bevalian, P.; Hashemi, A.; Bagheri, K.P. Highly Synergistic Effects of Melittin with Conventional Antibiotics against Multidrug-Resistant Isolates of Acinetobacter baumannii and Pseudomonas aeruginosa. Microb. Drug Resist. 2019, 25, 193-202. [CrossRef] [PubMed]

22. Utkin, Y.N. Animal venom studies: Current benefits and future developments. World J. Biol. Chem. 2015, 6, 28-33. [CrossRef] [PubMed]

23. Ortiz, E.; Gurrola, G.B.; Schwartz, E.F.; Possani, L.D. Scorpion venom components as potential candidates for drug development. Toxicon 2015, 93, 125-135. [CrossRef]

24. Kazemi, S.M.; Sabatier, J.-M. Venoms of Iranian Scorpions (Arachnida, Scorpiones) and Their Potential for Drug Discovery. Molecules 2019, 24, 2670. [CrossRef] [PubMed]

25. Chippaux, J.-P.; Goyffon, M. Epidemiology of scorpionism: A global appraisal. Acta Trop. 2008, 107, 71-79. [CrossRef] [PubMed]

26. Zabihollahi, R.; Bagheri, K.P.; Keshavarz, Z.; Motevalli, F.; Bahramali, G.; Siadat, S.D.; Momen, S.B.; Shahbazzadeh, D.; Aghasadeghi, M.R. Venom Components of Iranian Scorpion Hemiscorpius lepturus Inhibit the Growth and Replication of Human Immunodeficiency Virus 1 (HIV-1). Iran. Biomed. J. 2016, 20, 259-265. [PubMed]

27. Ahmadi, S.; Knerr, J.M.; Argemi, L.; Bordon, K.C.F.; Pucca, M.B.; Cerni, F.A.; Arantes, E.C.; Çalışkan, F.; Laustsen, A.H. Scorpion Venom: Detriments and Benefits. Biomedicines 2020, 8, 118. [CrossRef]

28. Yang, S.; Yang, F.; Zhang, B.; Lee, B.H.; Li, B.; Luo, L.; Zheng, J.; Lai, R. A bimodal activation mechanism underlies scorpion toxin-induced pain. Sci. Adv. 2017, 3, e1700810. [CrossRef]

29. Hakim, A.; Jiang, W.; Luo, L.; Li, B.; Yang, S.; Song, Y.; Lai, R. Scorpion Toxin, BmP01, Induces Pain by Targeting TRPV1 Channel. Toxins 2015, 7, 3671-3687. [CrossRef]

30. Rowe, A.H.; Xiao, Y.; Scales, J.; Linse, K.D.; Rowe, M.P.; Cummins, T.R.; Zakon, H.H. Isolation and Characterization of CvIV4: A Pain Inducing $\alpha$-Scorpion Toxin. PLoS ONE 2011, 6, e23520. [CrossRef] 
31. Torabi, E.; Behdani, M.; Chafi, M.H.; Moazzami, R.; Sabatier, J.; Khalaj, V.; Shahbazzadeh, D.; Bagheri, K.P. Characteristics and Lethality of a Novel Recombinant Dermonecrotic Venom Phospholipase D from Hemiscorpius lepturus. Toxins 2017, 9, 102. [CrossRef]

32. Sanaei-Zadeh, H. Painless Stings of Yellow Iranian Scorpions. Iran. Red Crescent Med. J. 2017, 19, 42645. [CrossRef]

33. Dehghani, R.; Arani, M.G. Scorpion sting prevention and treatment in ancient Iran. J. Tradit. Complement. Med. 2015, 5, 75-80. [CrossRef]

34. Pipelzadeh, M.H.; Jalali, A.; Taraz, M.; Pourabbas, R.; Zaremirakabadi, A. An epidemiological and a clinical study on scorpionism by the Iranian scorpion Hemiscorpius lepturus. Toxicon 2007, 50, 984-992. [CrossRef] [PubMed]

35. Dehghani, R.; Kamiabi, F.; Mohammadi, M. Scorpionism by Hemiscorpius spp. in Iran: A review. J. Venom. Anim. Toxins Incl. Trop. Dis. 2018, 24, 1-10. [CrossRef]

36. Pourkhalili, K.; Kim, E.; Mashayekhy, N.R.; Kamyab, M.; Hoseiny, S.M.; Evazy, R.; Mirakabadi, A.Z.; Seyedian, R. Cardiotoxic and Arrhythmogenic Effects of Hemiscorpius lepturus Scorpion Venom in Rats. J. Arthropod Borne Dis. 2015, 9, 215-225. [PubMed]

37. Shahbazzadeh, D.; Srairi-Abid, N.; Feng, W.; Ram, N.; Borchani, L.; Ronjat, M.; Akbari, A.; Pessah, I.N.; De Waard, M.; El Ayeb, M. Hemicalcin, a new toxin from the Iranian scorpion Hemiscorpius lepturus which is active on ryanodine-sensitive Ca2+ channels. Biochem. J. 2007, 404, 89-96. [CrossRef]

38. Jridi, I.; Catacchio, I.; Majdoub, H.; Shahbazeddah, D.; Ayeb, M.; Frassanito, M.A.; Ribatti, D.; Vacca, A.; Borchani, L. Hemilipin, a novel Hemiscor-pius lepturus venom heterodimeric phospholipase A2, which inhibits angiogenesis in vitro and in vivo. Toxicon 2015, 105, 34-44. [CrossRef] [PubMed]

39. Maleki, M.; Dounighi, N.M. Purification and characterization of a novel type of neurotoxic peptides from the venom of the Iranian scorpion Hemiscorpius lepturus. Iran. J. Basic Med. Sci. 2020, 23, 195-201.

40. Papadopoulos, J.S.; Agarwala, R. COBALT: Constraint-based alignment tool for multiple protein sequences. Bioinformatics 2007, 23, 1073-1079. [CrossRef]

41. Roy, A.; Kucukural, A.; Zhang, Y. I-TASSER: A unified platform for automated protein structure and function prediction. Nat. Protoc. 2010, 5, 725-738. [CrossRef]

42. Huang, C.C.; Meng, E.C.; Morris, J.H.; Pettersen, E.F.; Ferrin, T.E. Enhancing UCSF Chimera through web services. Nucleic Acids Res. 2014, 42, W478-W484. [CrossRef]

43. Eisapoor, S.S.; Jamili, S.; Shahbazzadeh, D.; Mostafavi, P.G.; Bagheri, K.P. A New, High Yield, Rapid, and Cost-Effective Protocol to Deprotection of Cysteine-Rich Conopeptide, Omega-Conotoxin MVIIA. Chem. Biol. Drug Des. 2016, 87, 687-693. [CrossRef] [PubMed]

44. Lopez-Vera, E.; Walewska, A.; Olivera, A.B.M.; Bulaj, G. Role of Hydroxyprolines in the in Vitro Oxidative Folding and Biological Activity of Conotoxins. Biochemistry 2008, 47, 1741-1751. [CrossRef] [PubMed]

45. Shahangian, S.S.; Sajedi, R.; Hasannia, S.; Jalili, S.; Mohammadi, M.; Taghdir, M.; Shali, A.; Mansouri, K.; Sariri, R. A conformationbased phage-display panning to screen neutralizing anti-VEGF VHHs with VEGFR2 mimicry behavior. Int. J. Biol. Macromol. 2015, 77, 222-234. [CrossRef]

46. Liu, X.; Yao, G.; Wang, K.; Liu, Y.; Wan, X.; Jiang, H. Structural and Functional Characterization of Conotoxins from Conus achatinus Targeting NMDAR. Mar. Drugs 2020, 18, 135. [CrossRef]

47. Guidance for Industry. Analgesic Indications: Developing Drug and Biological Products. Office of Communications, Division of Drug Information, Center for Drug Evaluation and Research, Food and Drug Administration. 02/06/2014. Available online: http: //www.fda.gov/Drugs/GuidanceComplianceRegulatoryInformation/Guidances/default.htm (accessed on 1 December 2020).

48. Moghadasi, Z.; Jamili, S.; Shahbazadeh, D.; Bagheri, K.P. Toxicity and Potential Pharmacological Activities in the Persian Gulf Venomous Sea Anemone, Stichodactyla haddoni. Iran. J. Pharm. Res. 2018, 17, 940-955.

49. Carlsson, K.-H.; Jurna, I. Depression by flupirtine, a novel analgesic agent, of motor and sensory responses of the nociceptive system in the rat spinal cord. Eur. J. Pharmacol. 1987, 143, 89-99. [CrossRef]

50. Regalado, A.I.; Mancebo, B.; Paixão, A.; López, Y.; Merino, N.; Sánchez, L.M. Antinociceptive Activity of Methanol Extract of Tabebuia hypoleuca (C. Wright ex Sauvalle) Urb. Stems. Med. Princ. Pract. 2017, 26, 368-374. [CrossRef] [PubMed]

51. Aghazadeh, H.; Memariani, H.; Ranjbar, R.; Bagheri, K. The activity and action mechanism of novel short selective LL-37-derived anticancer peptides against clinical isolates of Escherichia coli. Chem. Biol. Drug Des. 2019, 93, 75-83. [CrossRef]

52. Memar, B.; Jamili, S.; Shahbazzadeh, D.; Bagheri, K.P. The first report on coagulation and phospholipase A2 activities of Persian Gulf lionfish, Pterois russelli, an Iranian venomous fish. Toxicon 2016, 113, 25-31. [CrossRef] [PubMed]

53. Treuting, P.M.; Dintzis, S.M. Comparative Anatomy and Histology. In A Mouse and Human Atlas; Elsevier: London, UK, 2012; p. 461. ISBN 978-0-12-381361-9.

54. Bansinath, M.; Bose, A.C.; Hema, S.; Guruswami, M.N. Interaction of metamizol with some hypnotics in rats. Arch. Int. Pharmacodyn. Ther. 1982, 260, 14-27.

55. Nikolaev, M.V.; Dorofeeva, N.A.; Komarova, M.S.; Korolkova, Y.V.; Andreev, Y.A.; Mosharova, I.V.; Grishin, E.V.; Tikhonov, D.B.; Kozlov, S.A. TRPV1 activation power can switch an action mode for its polypeptide ligands. PLoS ONE 2017, 12, e0177077. [CrossRef]

56. Veber, D.; Milkowski, J.; Varga, S.; Denkewalter, R.; Hirschmann, R. Acetamidomethyl. A Novel Thiol Protecting Group for Cysteine. J. Am. Chem. Soc. 1972, 94, 5456-5461. [CrossRef] [PubMed] 
57. Becker, S.; Atherton, E.; Gordon, R.D. Synthesis and characterization of mu-conotoxin IIIa. JBIC J. Biol. Inorg. Chem. 1989, 185, 79-84. [CrossRef]

58. Steiner, A.M.; Bulaj, G. Optimization of oxidative folding methods for cysteine-rich peptides: A study of conotoxins containing three disulfide bridges. J. Pept. Sci. 2010, 17, 1-7. [CrossRef]

59. O'Brien, E.P.; Dima, R.I.; Brooks, B.; Thirumalai, D. Interactions between Hydrophobic and Ionic Solutes in Aqueous Guanidinium Chloride and Urea Solutions: Lessons for Protein Denaturation Mechanism. J. Am. Chem. Soc. 2007, 129, 7346-7353. [CrossRef] [PubMed]

60. Annis, I.; Hargittai, B.; Barany, G. [10] Disulfide bond formation in peptides. Branched Chain Amino Acids Part B 1997, $289,198-221$. [CrossRef]

61. Buczek, P.; Buczek, O.; Bulaj, G. Total chemical synthesis and oxidative folding of delta-conotoxin PVIA containing an N-terminal propeptide. Biopolymers 2005, 80, 50-57. [CrossRef]

62. Fan, X.; Zhao, F.; Wang, X.; Wu, G. Doxorubicin-triggered self-assembly of native amphiphilic peptides into spherical nanoparticles. Oncotarget 2016, 7, 58445-58458. [CrossRef] [PubMed]

63. Ummenhofer, W.C.; Arends, R.H.; Shen, D.D.; Bernards, C.M. Comparative Spinal Distribution and Clearance Kinetics of Intrathecally Administered Morphine, Fentanyl, Alfentanil, and Sufentanil. Anesthesiology 2000, 92, 739-753. [CrossRef] 